\title{
MACRO- AND MICROMORPHOLOGY OF THE STEMS AND LEAVES OF ASTERISCUS GRAVEOLENS
}

\author{
A.A. Attia and S.A. Youssef \\ Pharmacognosy Department, Faculty of Pharmacy, Assiut University, Assiut, Egypt
}

\begin{abstract}
The macro and micromorphology of the stems and leaves of Asteriscus graveolens, are presented aiming for their identification both in entire and powdered forms.
\end{abstract}

\section{INTRODUCTION}

Asteriscus graveolens L. $\quad(=$ Oclontospermum graveolens Sch, Bip) (F.compositae, tribe Inuleae, Subtribe Inulinae) is a common perennial herb known in Arabic as "Beheyma"1.

Current literature revealed the presence of falvonoids ${ }^{2}$, and humulene derivatives ${ }^{3}$.

Tracing the current literature nothing has been done concerning the macro- and micromorphology of the plant.

In the present study, the macro- and micromorphological investigation of the stems and leaves were performed in order to identify each organ in the entire and powdered forms.

\section{Material:}

The fresh, stems and leaves of Asteriscus graveolens were collected near mamer Metla, Sinai desert and in April (1992) identified by Prof. Dr. A.Fayed, Professor of Plant Taxonomy, Department of Botany, Faculty of Science, Assiut University. The separated parts were preserved in alcohol $70 \%$ containing 5\% glycerin. The powder material was obtained from air-dried plants.

\section{MACROMORPHOLOGY}

Habitat:

Asteriscus graveolens (Fig. 1) is a perennial herb with branches stem, $20-40 \mathrm{~cm}$ in height. The plant shows dentate or divided leaves, flower heads bright yellow ray tlorets ligulate, 3 toothed; heads large, several, terminal and in the forks of the branches Disk florets are actimorphis, sessile and hermaphrodites.

\section{1-The Stem (Fig. 1)}

It is erect, branched and hairy. It measures $20-40 \mathrm{~cm}$ in height and $0.5-1 \mathrm{~cm}$ in diameter. Externally, it is yellowish-brown in color with faint odor and characteristic taste.

\section{2-The Leaf (Fig. 1)}

The leaf is sessile alternate, simple dentate or divided and with more or less acute to acuminate apex about $2-4 \mathrm{~cm}$ and $0.5-1 \mathrm{~cm}$ in width. It has a yellowish-green color, odorless with a faint bitter taste. The midrib is big and prominent on both surfaces. The leaves show pinnate reticulate venations.

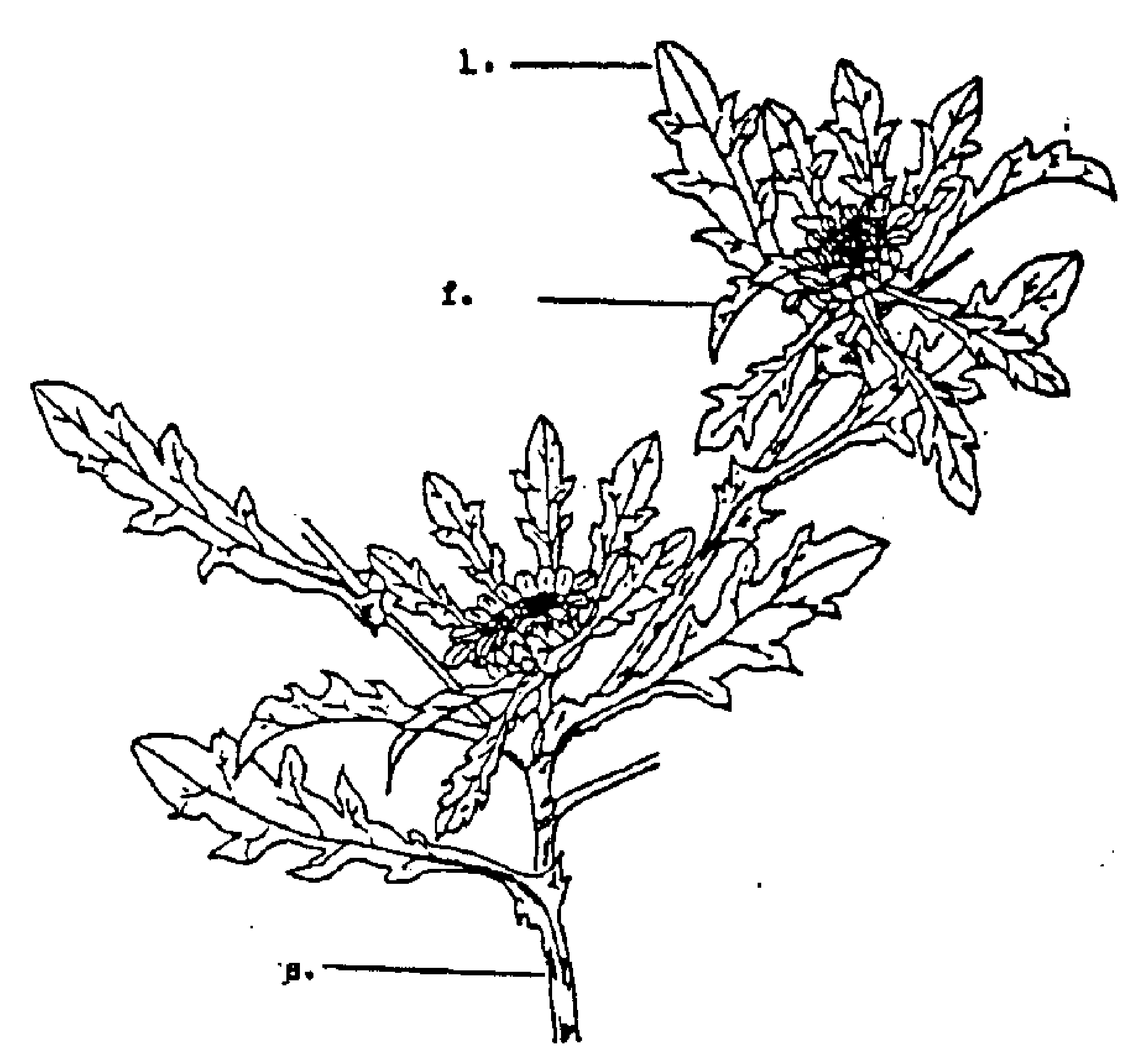

Fig. 1: Sketch of A Branch

$\mathrm{X} 1 / 6$

f., flower; 1., leaff; s., stem 


\section{MICROMORPHOLOGY}

\section{1-The Stem:}

A transverse section in the young stem (Fig. $2 \mathrm{~A}$ ) is more or less rounded in outline. It is formed of an epidermis carrying glandular trichomes, the cortex is formed of 2-3 rows of collenchymatous cells and 5-6 rows of parenchyma. The endodermis is distinct.

The pericycle consists of a group of fibers abutting the vascular bundles and interrupted by parenchyma, surrounding the central cylinder. The vascular tissue is formed of a number of collateral, separated bundles. Each bundle consists of an outer phloem and inner radiating xylem. The phloem and xylem are traversed by uni-or biseriate medullary rays. The central stele encloses a wide parenchymatous pith.

In old stem (Fig. 2B) the vascular tissue consists of a continuous ring of phloem and a continuous ring of xylem surrounding a wide central pith. The pericyclic fibers resemble that of the young stem.

The epidermis:(Fig. 2) is formed of one row of cells which are polygonal tabular tangentially elongated with straight, and thin, cellulosic anticlinal walls measuring form $40-100 \mu$ in length, $21-35 \mu$ in width and $11-20 \mu$ in diameter. They are covered with thin smooth cuticle carrying covering and glandular trichomes, stomata are not observed. The glandular trichomes are formed of unicellular stalk and multicellular (6-8 cells), biseriate, tabular head measuring from $140-160 \mu$ in length and $80-100 \mu$ in width. The non-glandular trichomes occur either as single or multicellular (2-4 cells), uniseriate with thin smooth cellulosic walls wide lumens and acute apices, measure from 100$266 \mu$ in length and 200-35 $\mu$ in width.

The cortex (Fig. 2C) is comparatively wide and formed of 6-8 rows of the walled parenchymatous cells.

The endodermis (Fig. 2C) is formed of thinwalled parenchymatous cells.

The pericycle (Fig. 2C) is formed of successive groups of fibers which are tangentially arranged. They have thick lignified walls, narrow lumen and acute apices measuring from $335-445 \mu$ in length, $25-33 \mu$ in width.
The phloem (Fig. 2C) is formed of phloem tissue consisting of sieve tubes, companion cells and phloem parenchyma.

The cambium (Fig. 2C) is represented by 2 3 rows of tangentially elongated, radially arranged, thin-walled meristematic cells.

The xylem (Fig. 2C) consists of lignified elements. The vessels (Fig. 2C) are solitary or in small groups of 2-3 vessels showing spiral and pitted thickening measuring from $33-45 \mu$ in diameter. The vessels are accompanied with tracheids, wood fibers and wood parenchyma. The fibers are abundant, spindle-shaped having thin-lignified walls, wide lumen and blunt or tapering apices measuring from $22-34 \mu$ in width. The wood parenchyma consist of elongated cells with pitted lignified walls. The medullary rays are 2-3 cells wide. The cells are radially elongated lignified and pitted in the xylem region but with non-lignified walls in the phloem region.

The pith (Fig. 2C) is formed of large more or less rounded wide parenchymatous cells and wider intercellular spaces, free from starch and calcium oxalate crystal.

Powdered stem (Fig. 3) is greenish-yellow in color, odorless and having somewhat bitter taste. It is characterized, microscopically by the following:

1- Fragments of polygonal mainly axially elongated epidermal cells with straight anticlinal walls and smooth cuticle, carrying non-glandular and glandular trichomes. Stomata are not observed.

2- Numerous glandular and covering trichomes.

3- Fragments of pericyclic fibers. With straight, thick, lignified walls, narrow lumen and blunt to rounded apices.

4- Wood fibers with straight, wide lumen acute ends.

5- Fragments of tracheids, wood parenchyma and medullary rays with pitted lignified walls.

6- Fragments of xylem vessels with spiral and pitted thickening.

7- Calcium oxalate and starch granules are not observed. 

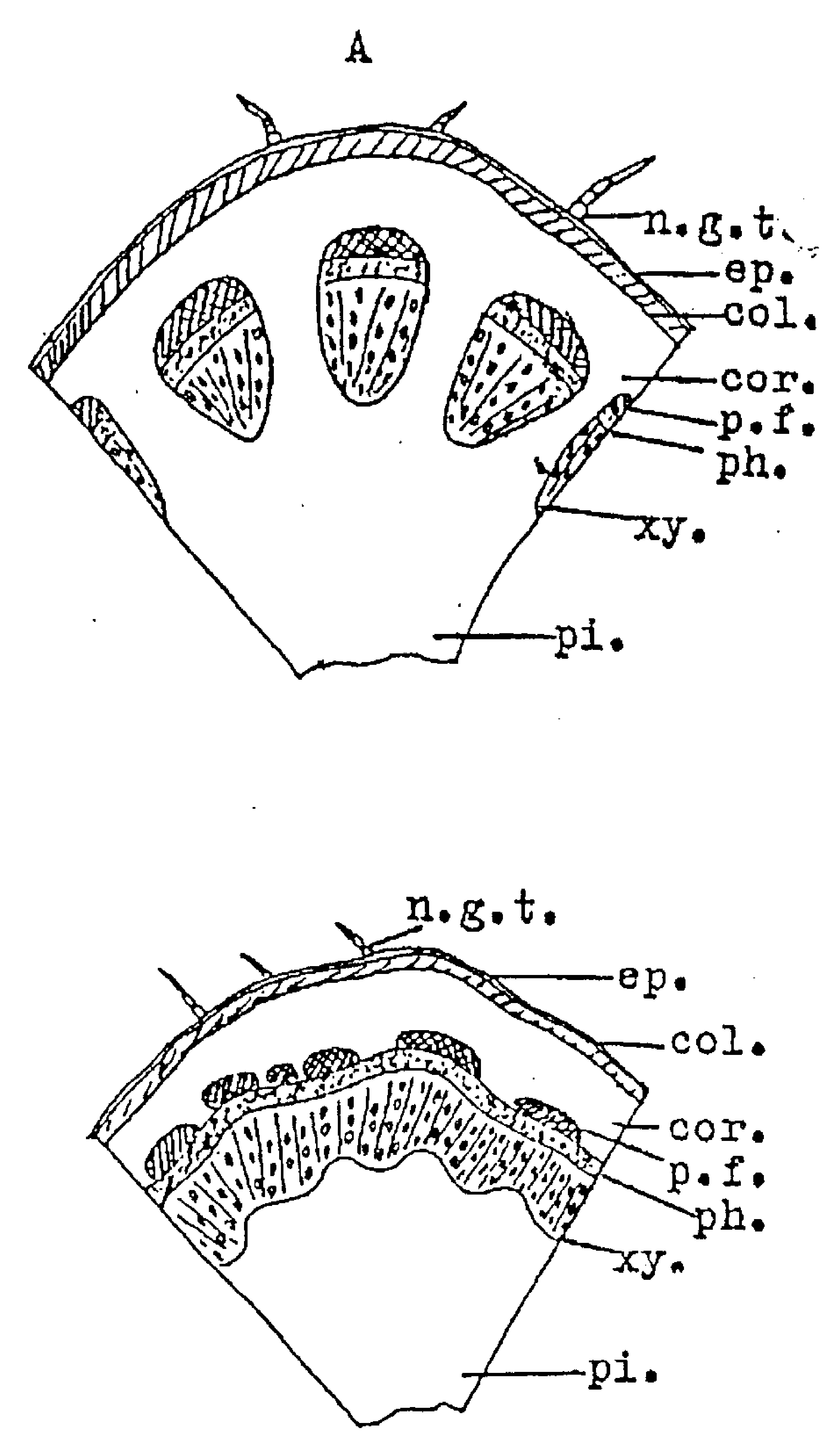

$B$

Fig. 2: A-Diagrammatic T.S. of young stem. X 19

B- Diagrammatic T.S. of old stem.

C-Detailed T.S. of young stem.

$\mathrm{X} 165$

Col., Collenchyma; cor., cortex; ep., epidermis; end., endodermis; m.r., medullary ray; p.f., pericyclic fibre; pi., pith; v., vessel; xy., xylem.

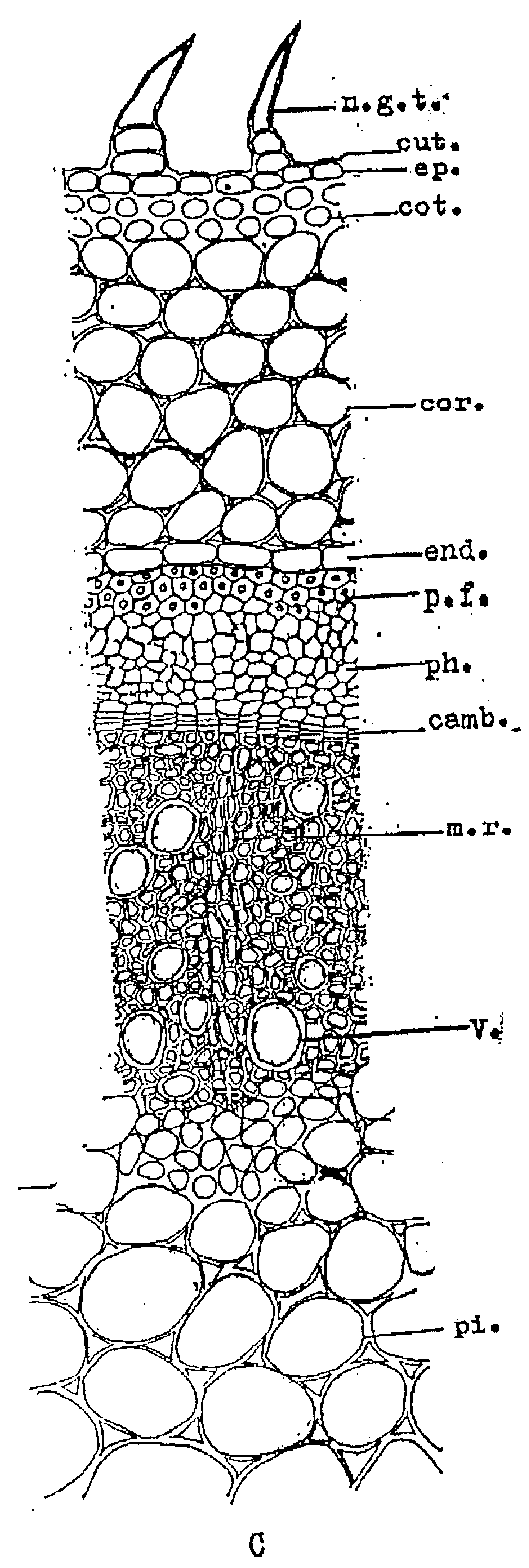


A
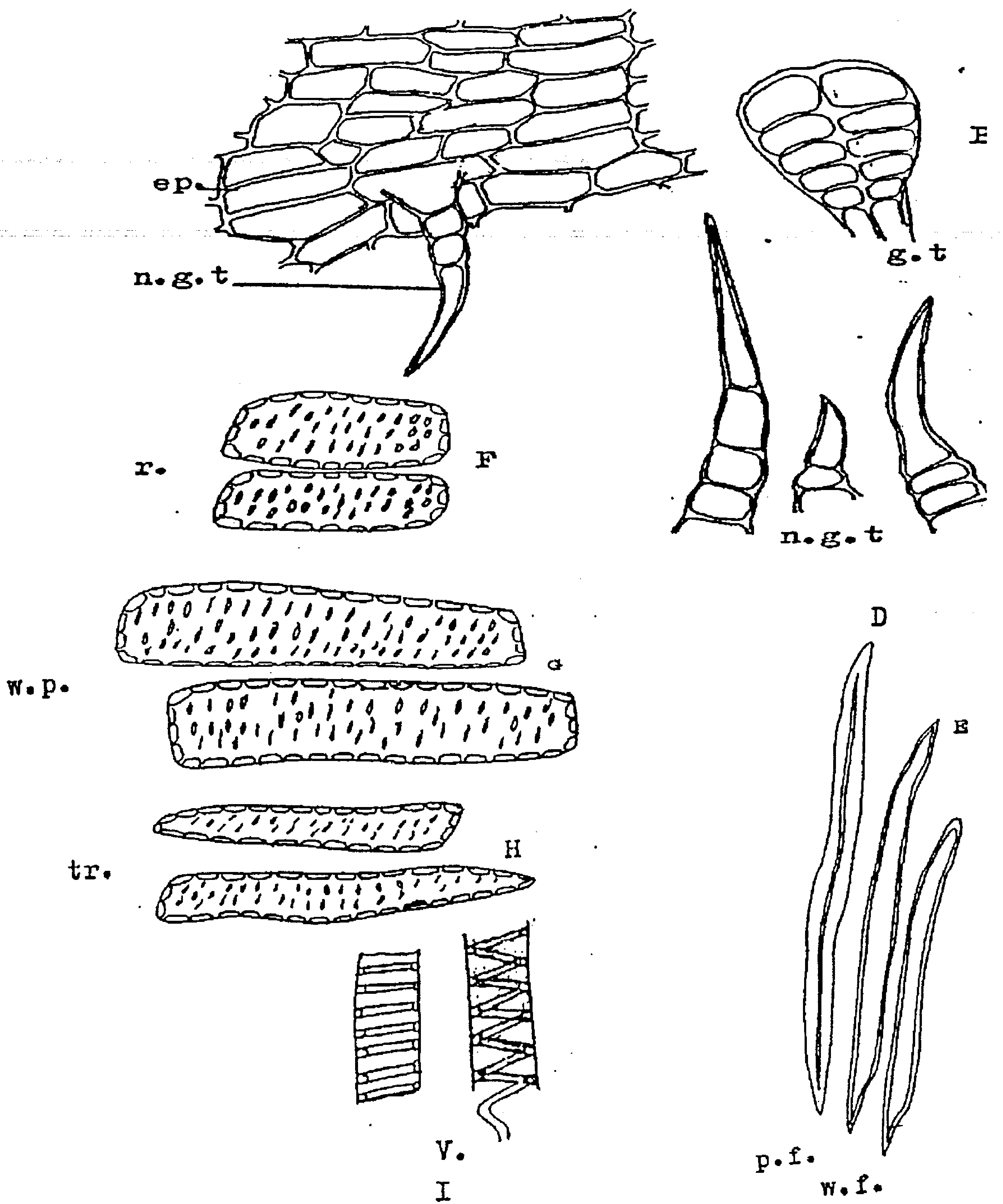

Fig. 3: A. Surface preparation of the stem B, C, D, E, F, G, H and I isolated elements of the stem ep., epidermis; g.t., glandular trichome; m.r., medullary ray; n.g.t., nonglandular trichome; p.f., pericyclic fibre; tr., tracheid; v., vessel; w.f., wood tibre; w.p., wood parenchyma. 


\section{II-The Leaf:}

A transverse section in the lamina through the midrib (Fig. 4A) appears biconvex in outline in the midrib region. It shows an upper and lower epidermis enclosing in between isobilateral mesophile and in the midrib region 2 vascular strands of 3 V.B. subepidermal collenchyma both epidermis.

Upper epidermis (Fig. 4 \& 5C) is formed of polygonal tabular cells with wavy thin-cellulosic anticlinal walls and covered with thin smooth cuticle. They measure from 22 to $34 \mu$ in length, 22 to $66 \mu$ in width and 11 to $16 \mu$ in height. The cells carry few glandular trichomes and numerous non glandular trichomes resembling those of the stem.

The lower epidermal cells (Fig. 5A) are polygonal nearly isodiametric to slightly elongated with wavy anticlinal walls and covered with thin smooth cuticle. They measure $22-66 \mu$ in length, $16-48 \mu$ in width and $13-21 \mu$ in height. The cells carry few glandular trichomes and non-glandular trichomes resembling those of the stem.

The stomata are present on both surfaces being more frequently on the lower one. They are oval in shape and of anomocytic type being surrounded by 3-5 epidermal cells.

The mesophile (Fig. 4B,C) is isobilateral. The palisade is formed of two layers of columnar cells, filled with chloroplasts. The spongy tissue consists of thin walled, rounded or slightly irregular cells with intercellular spaces.

The cortical tissue (Fig. 4B,C) is formed of an upper and lower subepidermal masses of collenchyma, each of 2-3 rows of polygonal collenchymatous cells with thick cellulosic walls showing no intercellular spaces. The rest of the cortical tissue is formed of almost rounded, large thin-walled parenchymatous cells, with intercellular spaces.

The vascular system (Fig. 4C) is represented in the midrib region by one central and 2 lateral and smaller vascular bundles. Each vascular bundle is collateral with xylem above and phloem below. A small batch of pericyclic fibre is present beneath each phloem tissue. The pericyclic fibers shows acute apices, wide lumen and lignified walls, measuring $323-500 \mu$ in length, $16-37 \mu$ in width.

The endodermis (Fig. 4C) is distinct and formed of polygonal elongated cells.

The phloem (Fig. 4C) is formed of small, thin-walled shining cellulosic cells, hardly differentiated into sieve tubes, companion cells and phloem parenchyma. The cambium is indistinct.

The xylem (Fig. 4C) is formed of lignified vessels fibers and wood parenchyma. The vessels (Fig. 5C) are lignified showing spiral and annular thickening of $28-40 \mu$ in diameter.

The fibers (Fig. 5C) have thickened and lignified walls with tapering apices, they measure $266-350 \mu$ in length and $22-40 \mu$ in width. The wood parenchyma (Fig. 5C) are abundant with pitted and lignified walls.

\section{The Powder and Isolated elements}

Powdered leaf (Fig. 5C) is green in color, odorless and has faint bitter taste, it is characterized microscopically by the following:

1- Fragments of palisade cells.

2- Fragments of upper and lower epidermal cells.

3- Numerous glandular and non-glandular trichomes.

4- Fragments of lignified vessels with spiral and pitted thickening.

5- Fragments of wood fibers with wide lumen and acute to acuminate apices.

6- Fragments of wood parenchyma which are pitted and lignified.

7- Fragments of pericyclic fibers with wide lumen, shorter than the wood fibers.

8- No calcium oxalate or starch granules were detected. 

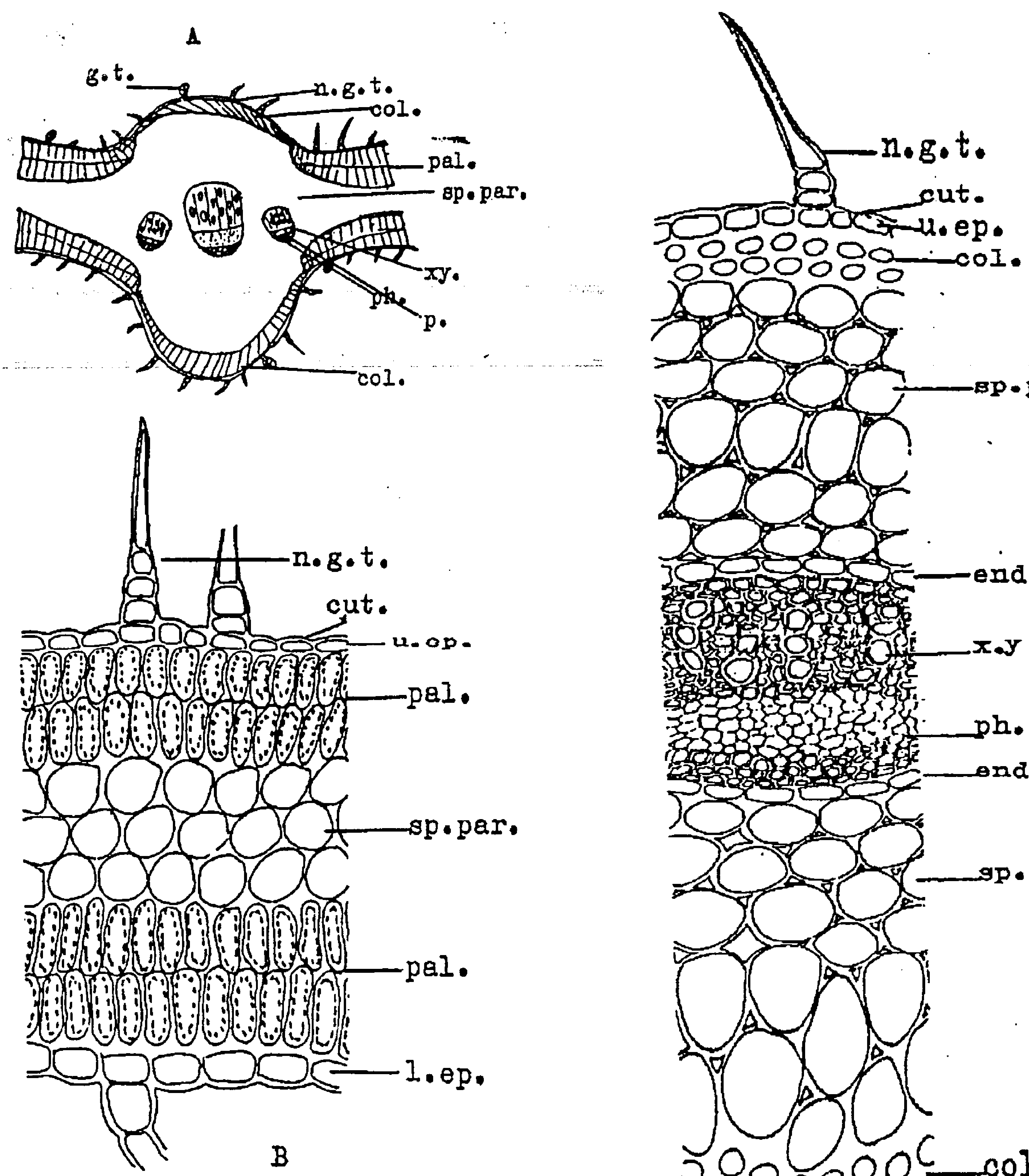

Fig. 4: A- Diagrammatic T.S. of the leaf.

B- Detailed T.S. of the leaf.

C- Detailed T.S. of the leaf.

col., collenchyma; end., endodermis; g.t., glandular trichomes; n.g.t., nonglandular trichome; l.ep., lower epidermis; pal., palisade; p., pericycle; ph., phloem; u.ep., upper epidermis; v., vessel; sp.par., spongy parenchyma; $x y .$, xylem.

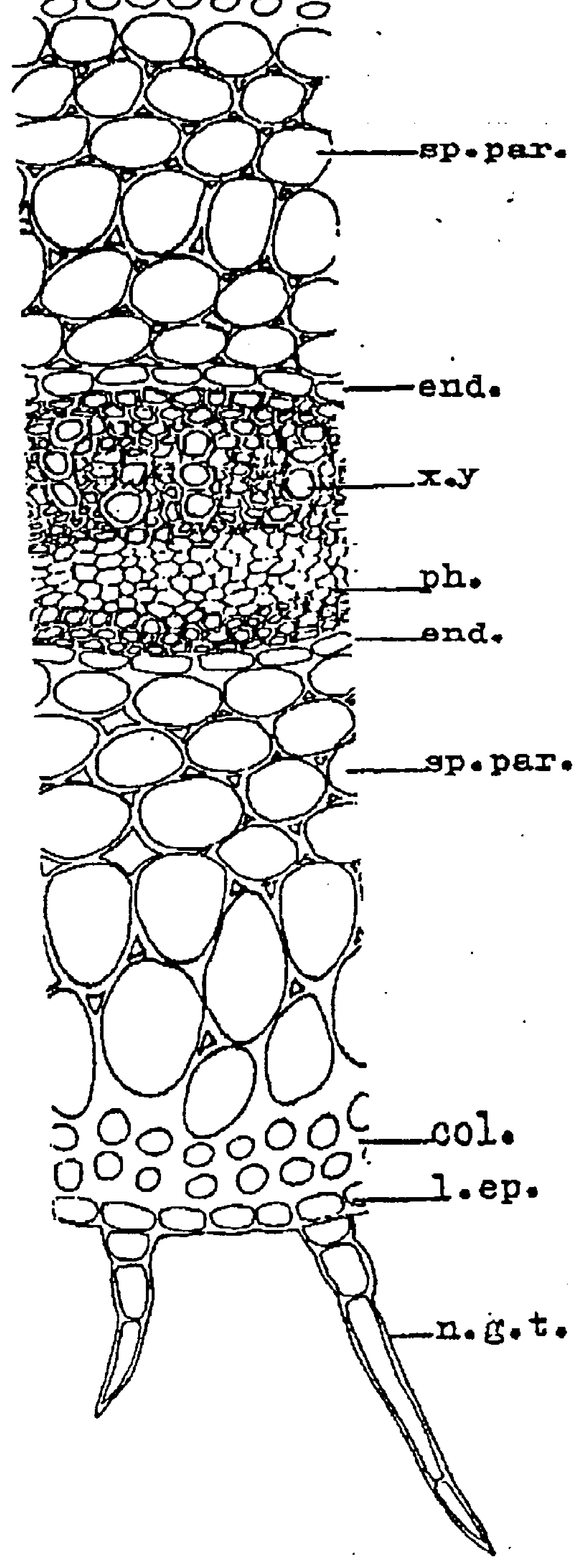




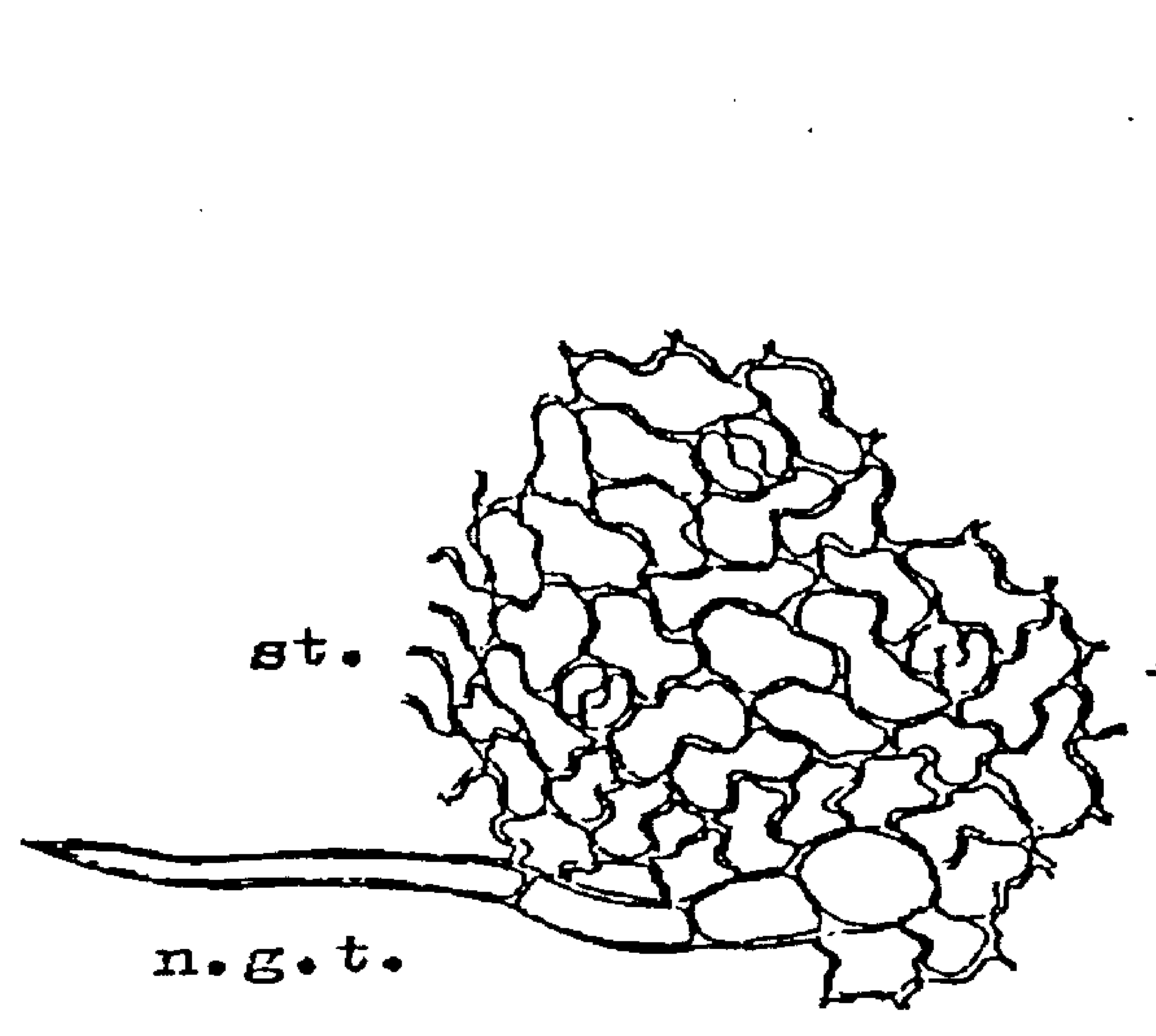

A

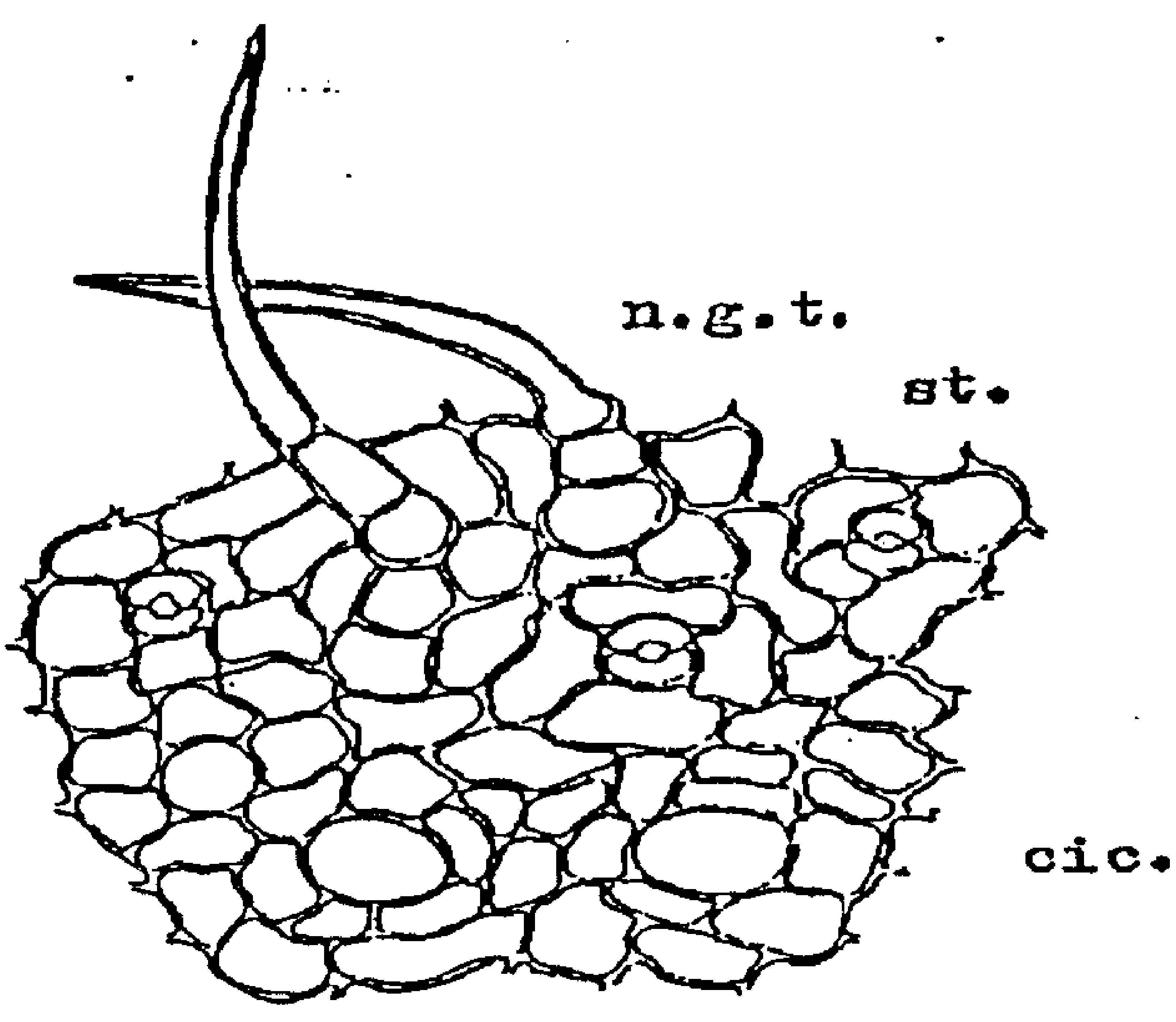

B

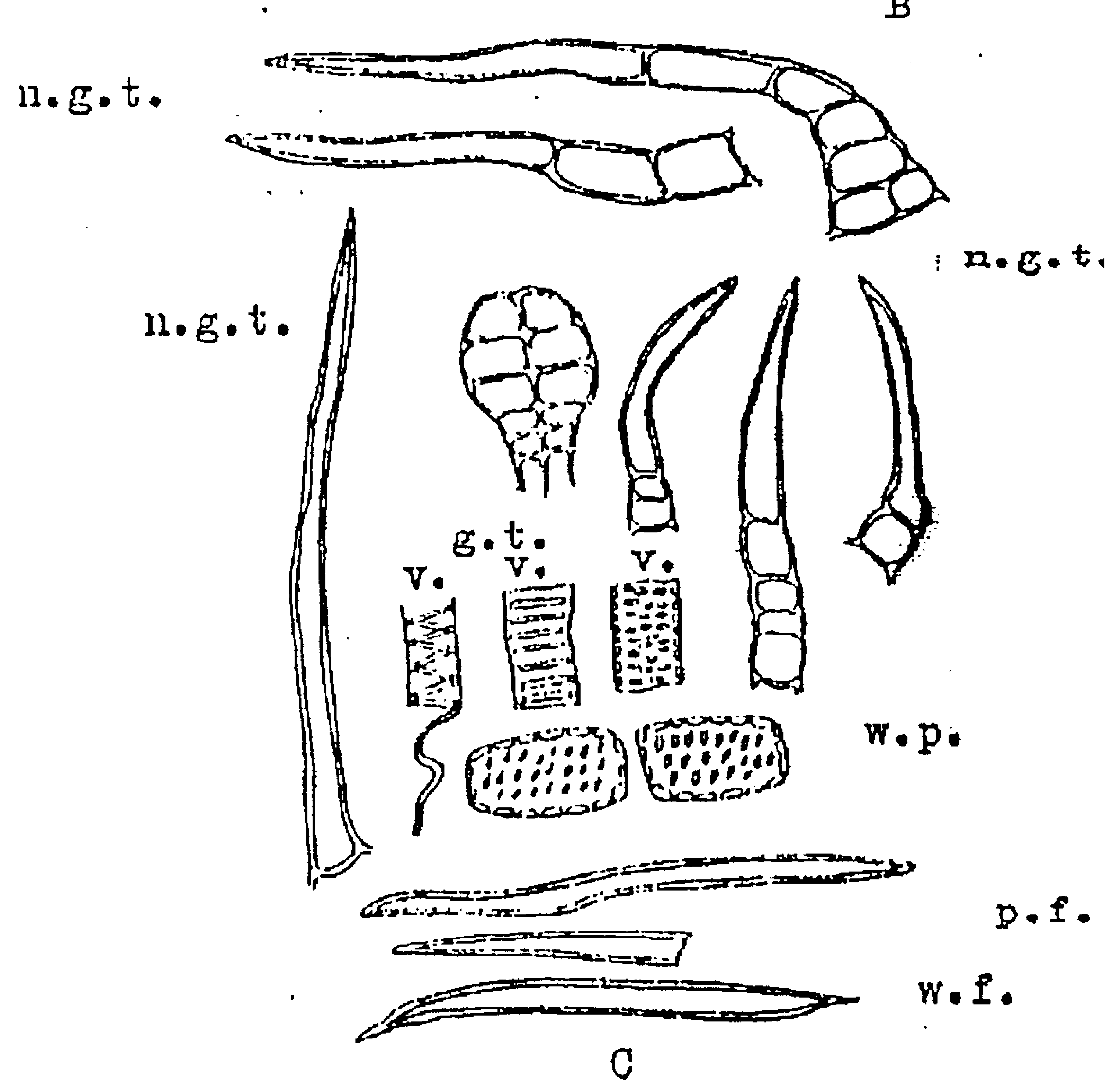

Fig. 5: A- Surface preparation of the leaf (lower epidermis).

B- Surface preparation of the leaf (upper epidermis).

C- Isolated elements of the leaf.

cic., cicatric; g.t., glandular trichome; n.g.t., nonglandular trichome; p.f., pericyclic fibre; st., stomata; v., vessel; w.f., wood fibre; w.p., wood parenchyma. 


\section{REFERENCES}

1- V.I. Tackholm; "Student's Flora of Egypt", 2nd Ed. University Cairo, 590 (1974).

2- A.A. Ahmed, M.S.Ishak, H.N.Micheal, M.A.El-Ansari and H.I. El-Sisi; (1991)
Flavonoids of Asteriscus graveolens, J. Nat.Prod. 54, 1092-1093.

3- S. El-Dahmy, J. Jakupovic, F. Bohlman and T.M.Sarg, Tetrahedron, 41, 309 (1985).

$$
\begin{aligned}
& \text { الصفات العيانية والمجهرية لسيقان وأوراق نبات } \\
& \text { الاستر بسكس بريك افيولينز } \\
& \text { أحمد عابدين عطية - سامية عباس يوسف بهن } \\
& \text { تسم العقاتير - كلية الصيدلة - جامعة اسيوط يسية }
\end{aligned}
$$

تدت الدراسة العيانية والمجهرية لسيقان وأوراق نبات الاستربسكس جرافيولينز - وذلك بغرض

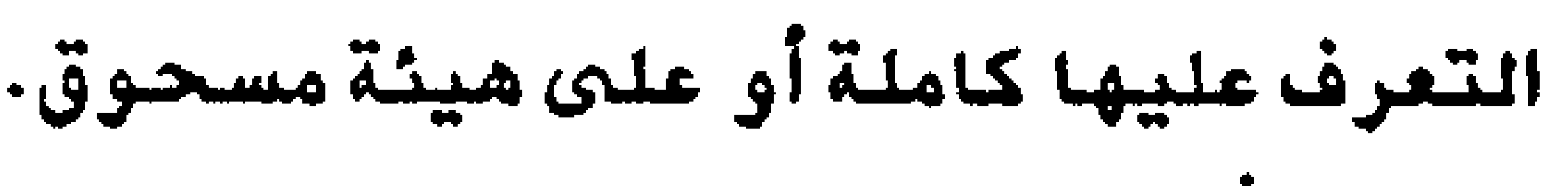

